\title{
Convergence of specified RUNX2, SALL1, and $S A M D 9$ variants permits normal global immune and endocrine function despite bone marrow hypocellularity and reduced ovarian reserve
}

E Scott Sills ( $D$ ess@prp.md)

CAG/FertiGen Corp https://orcid.org/0000-0001-7334-1031

Conor Harrity

Beaumont Hosp/RCSI https://orcid.org/0000-0001-6528-9704

Samuel H Wood

G5F San Diego

Short Report

Keywords: RUNX2, SALL1, SAMD9, ovary, renal, hematopoiesis

Posted Date: February 15th, 2022

DOI: https://doi.org/10.21203/rs.3.rs-1358972/v1

License: () (1) This work is licensed under a Creative Commons Attribution 4.0 International License.

Read Full License 


\section{Abstract \\ Background}

RUNX2, SALL 1 and SAMD9 are independently assorted genes responsible for multisystem actions where disruption often results in severe developmental or functional impairment. Alteration in any of these 'master regulators' is usually diagnosed in early childhood when missed milestones, anatomical dysmorphia, or chronic infection/immune impairment initiate cross-disciplinary evaluation.

\section{Methods}

New variants were recently discovered in all three genes during SARS-CoV-19 hospitalization in an otherwise healthy $46, \mathrm{XX}$ adolescent. Our research expands the clinical characterization for this unusual convergence based on medical records covering the 5 year interval before admission.

\section{Results}

Diffuse bone marrow hypocellularity without cytogenetic derangement was present, with no anemia or reduction in total immunoglobulin production. However, bone age was below mean by $1.5 y$ rs and multiple dental anomalies were documented. Macrocytosis and elevated serum creatinine were consistent findings. Ovaries and uterus appeared undersized with collapse of endogenous estradiol output leading to secondary amenorrhea by age $13 y r s$. Besides oral contraceptives, no other daily hormone treatment was required. A TSH receptor gene mutation of uncertain significance was also identified.

\section{Conclusions}

This is the first work to correlate immunoglobulin patterns, bone marrow and dental morphology, hematology/renal screening, pelvic anatomy, ovarian reserve data and thyroid features with coincident variants in RUNX2, SALL1 and SAMD9. While the expected impact from each mutation alone would normally be adverse, this study suggests a milder phenotype can prevail when these three variants occur together. Nevertheless, focused monitoring is appropriate given the uncertain status of this unique combination of mutations.

\section{Introduction}

A 'chief conductor' driving cartilage formation and skeletal development, $R U N X 2$ is a gene with at least 200 known mutations. Several such variants can manifest as cleidocranial dysplasia, a condition with delayed fontanel closure, enlarged head circumference, clavicular dysmorphia, abnormal dentition, short stature, or hand defects [1]. The frequency of $R U N X 2$ variants in the general population may be as low as $0.4 \%$ [2]. Spalt-like transcription factor 1 gene (SALL1) broadly controls DNA packaging and chromatin 
remodeling. This gene also coordinates female urogenital structure, and Mullerian defects can occur with its mutation [3]. SALL1 also modulates human tumorigenesis with $>70$ variants now associated with Townes-Brocks syndrome (i.e., otic, limb, renal, and anal anomalies) [4]. Such mutations occur with uncertain frequency, but from $>3,000$ targets with putative association to single gene disorders, SALL1 was among the least common [5]. The gene for SAMD9 (sterile a motif domain-containing protein 9) localizes to a region frequently involved in myeloid malignancies, blood dyscrasias, and childhood immune impairments. That $S A M D 9$ might be causative in certain hematologic disorders was first advanced by Asou et al [6] who linked microdeletions at this locus with myeloid malignancies. Germline missense SAMD9 changes were subsequently implicated in a constellation of features termed MIRAGE syndrome [7] consisting of myelodysplasia, infection, restricted growth, adrenal hypoplasia, genital anomaly, and enteropathy. Fewer than 50 cases of this syndrome have been described [8]. The severe pathobiological consequences of RUNX2, SALL1, or SAMD9 variants have limited opportunities for longitudinal follow-up, and alteration of all three in combination has only been encountered once [9]. The current project was undertaken to expand the clinical characterization of this atypical genetic confluence during the adolescent-to-adulthood transition.

\section{Methods}

As none of the 3 newly discovered variants here were accessioned by any public genome library, a priori pathogenicity estimates could not be calculated. Prior to the current case, the only known nexus involving the three genes of interest was from experimental animal research [10]. Accordingly, precautionary bone marrow biopsy was advised to provide tissue for genome wide single nucleotide polymorphism (SNP) microarray analysis (Illumina Infinium CytoSNP-850Kv1.2 BeadChip; San Diego CA). With diseaseassociated gene centric content of $>800 \mathrm{~K}$ SNP loci from chromosomes 1-22, $>29 \mathrm{~K}$ and $>2 \mathrm{~K}$ loci from $\mathrm{X}$ and $\mathrm{Y}$ chromosomes, respectively, this platform offered resolution of $\sim 1$ probe every $4 \mathrm{~kb}$ with an extra 110,000 probes interrogating at least four pathology-associated genes, as per ABMG consortium opinion. Nucleotide positions were mapped using the February 2009 assembly of the human reference sequence [11].

Medical information for this intake was gathered after proband's high school graduation to prepare for relocation to university. Laboratory tests, pathology slides, $x$-rays, and chart notes for the period corresponding to ages 13-18yrs were then matched with key health events based on patient narrative, contemporary notes, discussion with care team members, and parental interviews. Exome sequence analysis as part of a multispecialty workup related to Covid-19 hospitalization and ICU transfer was completed in 2021, followed by renal biopsy. Molecular characterization for the patient (and both nonconsanguineous parents) provided an informative pedigree identifying novel variants in RUNX2, SALL1 and $S A M D 9$, as previously described [9].

\section{Results}


Complete blood counts (CBC) were analyzed from routine check-ups between 2016 and 2021, when the patient's most recent $\mathrm{BMI}$ was $17.8 \mathrm{~kg} / \mathrm{m}^{2}$. While $\mathrm{CBC}$ data included marginally abnormal indices and occurred with no discernable pattern, the exception was mean corpuscular volume (MCV) which was consistently elevated. The patient had long taken multivitamin supplements for this macrocytosis, and serum folate was normal at $777 \mathrm{ng} / \mathrm{mL}$. Platelet (PLT) concentration remained within the standard range during the review period although mean PLT volume (MPV) was not measured at every visit. When available, MPV was slightly low (data not shown). Flow cytometry immune testing identified nominally elevated $\mathrm{CD}^{+}$(ratio) and $\mathrm{CD} 8^{+}$(absolute) cells, an upward shift in the $\mathrm{CD} 4^{+} / \mathrm{CD} 8^{+}$ratio, and markedly suppressed natural killer cells. Serum IgA and IgG levels were also marginally reduced, despite normal total immunoglobulin and IgM levels (see Table 1). Serum blood urea nitrogen (BUN) and creatinine levels were unrelated to any concurrent CBC fluctuations (see Fig. 1a \& 1b).

Whole blood analysis on morning of bone marrow biopsy showed erythrocyte (RBC), hemoglobin, and hematocrit at $3.3 \times 10^{6} / \mathrm{uL} .11 .8 \mathrm{~g} / \mathrm{dL}$, and $36.1 \%$, respectively. Leukocyte count (WBC) was normal at $5.7 \mathrm{~K} / \mathrm{uL}$ (reference range $=4.4-9.7$ ). Both $\mathrm{MCV}$ and mean corpuscular hemoglobin were elevated at $106.8 \mathrm{fL}$ and $34.9 \mathrm{pg}$. PLT count was normal at $182 \mathrm{~K} / \mathrm{uL}$. Generalized bone marrow hypocellularity was observed with trace storage iron, decreased erythroid precursors with mildly megaloblastoid maturation, decreased granulocyte precursors with full maturation, and normal megakaryocytes (see Fig. 2a \& 2b). Myeloid:erythroid precursor ratio was normal on core analysis, and no increased fibrosis was evident on reticulin stain. Marrow sample showed high lymphocytes and monocytes ( 43.5 and $6 \%$, respectively), low bands $(5.5 \%$; reference range $=17-33)$ and nominally elevated orthochromatic normoblasts $(7.5 \%$; reference range $=1-5)$. Fluorescent in situ hybridization demonstrated a normal signal with no copy number variance in nuclei $(n=200)$. Bone marrow cytogenetics verified a non-mosaic $46, X X$ karyotype, aligning with results obtained earlier from peripheral (somatic) samples. Fragile $X$ carrier panel was negative.

By age 7yrs, all deciduous teeth were succeeded by permanent teeth, although anomalous non-descent of left cuspid was incidentally identified during pre-orthodontic screening. In addition, panoramic x-ray at age 17yrs revealed multiple underdeveloped roots and secondary loss of right lateral incisor. Surgery to remove all four impacted wisdom teeth (see Fig. 3 ) is scheduled.

Menarche was at age $11 \mathrm{yrs}$ but within two years menses had ceased. At age 15.5yrs, low-dose oral contraceptives were initiated to restore cyclicity and no other hormonal therapy was ever prescribed. Serum FSH was consistently $>100 \mathrm{mIU} / \mathrm{ml}$ with anti-Mullerian hormone below measurement threshold (< $0.015 \mathrm{ng} / \mathrm{mL}$ ). Small ovaries were seen on abdominal ultrasound including sparse but active bilateral follicular response on clomiphene challenge test, and pre-replacement serum estradiol levels were regularly $<5 \mathrm{pg} / \mathrm{mL}$, all indicative of diminished ovarian reserve [12]. Anti-ovarian antibody test was negative. At age 15yrs, bone age via standard radiograph [13] was $2 \mathrm{~cm}$ below mean, consistent with age 13.5yrs. At age 16, a solitary $2 \mathrm{~cm}$ right anterior neck mass was evaluated; laboratory tests were negative for autoimmune involvement and found no evidence of abnormal thyroid or parathyroid function. The structure was non-tender and was palpable only after singing. Fine needle aspiration of the lesion 
showed Bethesda category III cytology; molecular testing [14] found a missense c.1358T > C mutation in the TSH receptor gene [15] with variant allele frequency of $46 \%$, negative for gene fusions or copy number variants.

\section{Discussion}

Transcription factors set the pace and pattern of nuclear DNA conversion to mRNA. From amidst more than 1500 such factors, RUNX2, SALL1, and SAMD9 are especially prominent. The genes coding for these products thus control cell division, migration, body plan architecture, and apoptosis. While any disruption of these factors typically is poorly tolerated, often catastrophic, and usually apparent in childhood, this patient experienced an active, healthy childhood while carrying previously unreported variants in all three. Remarkably, the most dramatic highlight against a rather ordinary pediatric background was hospitalization for Covid-19. Attribution of findings discussed here to genetic etiologies vs. Covid-19 is challenging, given the unclassified status of these specified variants and the expansive, evolving nature of 'Long Covid'. Curiously, the high MPV seen with Covid-19 infection documented by others [16] was absent here. Perhaps the three variants dampened MPV by altering individual platelet responsiveness, even though overall platelet output was unaffected. Likewise, the observed low serum IgA and IgG levels alongside normal total immunoglobulin may reflect a synthesis of coordinated action by these variants.

To date, some 150 mutations in SAMD9 have been associated with outcomes ranging from spontaneous remission to malignant progression [17]. Most $S A M D 9$ variants presage early death from myeloid dysplasia, immune system imbalance, adrenal insufficiency, or chronic undernourishment from feeding difficulty [18]. SAMD9 mutations via germline transmission predispose to low platelets, acquired monosomy 7, constitutional abnormalities (e.g., ambiguous genitalia) and immune dysfunction [19]. Less is known about $S A M D 9$ variants which appear as de novo events. Computer modeling has envisioned a protein-protein interaction network of differentially expressed genes, and human SAMD9 was among the 'hub genes' having special relevance after SARS-CoV-2 infection [20]. Thomas et al [21] assessed the functional impact of wild-type and mutant $S A M D 9$ in primary mouse or human hematopoietic stem and progenitor cells. Using protein interactome analyses, transcriptional profiling, and functional validation, it was concluded that SAMD9 mutations tend to favor interference with DNA damage repair, and ultimately apoptosis, in hematopoietic cells [21]. The hypocellular terrain noted here on bone marrow biopsy may be a partial expression of this $S A M D 9$ influence.

RUNX2 is considered to be a centrally regulating transcription factor for osteoblast and chondrocyte differentiation and overall skeletal architecture [22, 23]. Some 80 variants in RUNX2 have been identified $[1,24]$ and while heterozygous loss of function mutations can lead to cleidocranial dysplasia, this is inconsistent [25]. Triplication [26] or quadruplication [27] of RUNX2 accompanies more serious syndromic phenotypes, including coronal/sagittal synostosis or pan-craniosynostosis $[26,27]$ suggesting a dosage effect [28]. For our patient, sequence analysis did identify a 3' duplication involving at least exons 6 through 9 of $R U N X 2$ [9], so connecting osseous and dental changes observed here as related to this gene variant seems plausible. 
In late adolescence or early adulthood third molar impaction is not unusual, and others have investigated differential expression of $R U N X 2$ regarding tooth location before surgical removal [29]. While RUNX2 was not implicated, another transcription factor (MSX1) was differentially expressed depending on depth of molar impaction [29] and RUNX2 is itself partially controlled by MSX1 [30]. As alveolar bone remodeling is central to orthodontic tooth movement, a novel regulatory mechanism whereby FOXO3 induces osteocalcin transcription by promoter activation in concert with RUNX2 [31] could help explain dental features in this case.

The T > C mutation in codon 453 of the TSH receptor gene found here was previously reported in the setting of nonautoimmune hyperthyroidism [32] but without any RUNX2, SALL1, or SAMD9 involvement. Wide tissue expression of TSHRs is well established, and includes brain, bone marrow, lymphocytes, pituitary, thymus, testes, kidney, adipose tissue, and fibroblasts [33]. While oocyte growth is influenced via TSHR/CAMP signaling [34], there has been no reason to obtain ovarian tissue sampling in this patient. Pelvic ultrasound will be useful to identify any changes in gross ovarian anatomy. Similarly, tracking thyroid size, nodularity, and tenderness, as well as the thyroid laboratory panel will be important.

Concerning SALL1, some 50 different mutations are currently known [35]. SALL1 and RUNX2 may have special relevance in human reproduction. Mammalian estrogen receptor $\beta(E R \beta)$ is required for ovarian follicles to advance past the antral stage, and work in rat granulosa cells has placed RUNX2 within the ERß-regulated genes directing folliculogenesis, oocyte maturation, and ovulation [36]. While SALL1 is essential for stem cell maintenance in kidney, heart, and spermatogonial progenitors [4,37], its role in human ovarian tissue awaits better characterization. Should undetectable serum AMH persist and ovarian histology be normal, this patient may consider fertility treatment including platelet-rich plasma for 'ovarian rejuvenation' [38] as an alternative to donor egg IVF.

The Venn diagram for worldwide clinical experience with RUNX2, SALL1, and SAMD9 returned a null union set, prior to this patient. The detrimental consequences of mutation of these genes in isolation may have been mitigated by the chance occurrence of all three variants in concert-an offset possibly enabled by cross-gene effects or epigenetic silencing [9]. Monitoring for patients with a SAMD9 variant includes CBC with differential every six months, and repeat bone marrow aspirate/biopsy (and karyotype) should anemia, thrombocytopenia, or neutropenia develop [8]. Red blood cell dysplasia, agglutination, or fragmentation are unlikely given the low/normal red-cell distribution width measured here. Serum BUN and creatinine levels evidenced no discernable pattern whenever these were abnormal, but as cystatin-C may be superior to BUN/Cr to detect early-stage disease $[39,40]$ a screening panel including all three will guide the need for repeat renal biopsy. Since this case incorporates a de novo variant, the risk to siblings is considered somewhat greater than the general population [8] and cytogenetic testing for an older halfbrother is pending. Clinical guidelines for RUNX2 or SALL 1 have not been developed, probably due to the exceptionally low frequency of these variants. Because not all instances of marrow hypocellularity will render immediate effects [41] periodic reassessment of this patient is planned.

\section{Declarations}




\section{Authors' Contributions}

ESS developed the research plan and organized initial drafts; ESS, $\mathrm{CH}$, and SHW reviewed the literature; SHW supervised the project and editorial aspects. All authors read and approved the final manuscript.

\section{Funding}

No support was received from any funding agency in public, commercial, or nonprofit sectors.

\section{Conflicts of Interest}

The authors have no conflicts to disclose.

\section{References}

1. Hansen L, Riis AK, Silahtaroglu A, Hove H, Lauridsen E, Eiberg $H$, et al. RUNX2 analysis of Danish cleidocranial dysplasia families. Clin Genet 2011;79(3):254-63. doi: http://dx.doi.org/10.1111/j.1399-0004.2010.01458.x

2. Morrison NA, Stephens AA, Osato M, Polly P, Tan TC, Yamashita N, et al. Glutamine repeat variants in human RUNX2 associated with decreased femoral neck BMD, broadband ultrasound attenuation and target gene transactivation. PLoS One 2012;7(8):e42617. doi:

http://dx.doi.org/10.1371/journal.pone.0042617

3. Tian W, Chen N, Ye Y, Ma C, Qin C, Niu Y, et al. A genotype-first analysis in a cohort of Mullerian anomaly. J Hum Genet 2022 Jan 13. doi: http://dx.doi.org/10.1038/s10038-021-00996-w

4. Álvarez C, Quiroz A, Benítez-Riquelme D, Riffo E, Castro AF, Pincheira R. SALL proteins; common and antagonistic roles in cancer. Cancers (Basel) 2021;13(24):6292. doi: http://dx.doi.org/10.3390/cancers13246292

5. López-Rivera JA, Pérez-Palma E, Symonds J, Lindy AS, McKnight DA, Leu C, et al. A catalogue of new incidence estimates of monogenic neurodevelopmental disorders caused by de novo variants. Brain 2020;143(4):1099-105. doi: http://dx.doi.org/10.1093/brain/awaa051

6. Asou H, Matsui H, Ozaki Y, Nagamachi A, Nakamura M, Aki D, et al. Identification of a common microdeletion cluster in 7q21.3 sub-band among patients with myeloid leukemia and myelodysplastic syndrome. Biochem Biophys Res Commun 2009;383(2):245-51. doi: http://dx.doi.org/10.1016/j.bbrc.2009.04.004

7. Narumi S, Amano N, Ishii T, Katsumata N, Muroya K, Adachi M, et al. SAMD9 mutations cause a novel multisystem disorder, MIRAGE syndrome, and are associated with loss of chromosome 7. Nat Genet 2016;48(7):792-7. doi: http://dx.doi.org/10.1038/ng.3569 
8. Tanase-Nakao K, Olson TS, Narumi S. MIRAGE Syndrome. In: Adam MP, Ardinger HH, Pagon RA, Wallace SE, et al (eds). GeneReviews, Seattle (WA): University of Washington, Seattle, 1993-2022. doi: https://www.ncbi.nlm.nih.gov/books/NBK564655/

9. Sills ES, Wood SH. Phenotype from SAMD9 mutation at 7p21.1 appears attenuated by novel compound heterozygous variants at RUNX2 and SALL1. Global Med Genet 2022: in press. doi: http://dx.doi.org/10.1055/s-0041-1740018

10. Lin Y, Xiao Y, Lin C, Zhang Q, Zhang S, Pei F, et al. SALL1 regulates commitment of odontoblast lineages by interacting with RUNX2 to remodel open chromatin regions. Stem Cells 2021;39(2):196209. doi: http://dx.doi.org/10.1002/stem.3298

11. Axelrod N, Lin Y, Ng PC, Stockwell TB, Crabtree J, Huang J, et al. The HuRef Browser: a web resource for individual human genomics. Nucleic Acids Res 2009;37(database issue):D1018-24. doi: http://dx.doi.org/10.1093/nar/gkn939

12. Sills ES, Alper MM, Walsh AP. Ovarian reserve screening in infertility: practical applications and theoretical directions for research. Eur J Obstet Gynecol Reprod Biol 2009;146(1):30-6. doi: http://dx.doi.org/10.1016/j.ejogrb.2009.05.008

13. Jang WY, Ahn KS, Oh S, Lee JE, Choi J, Kang CH, et al. Difference between bone age at the hand and elbow at the onset of puberty. Medicine (Baltimore) 2022;101(1):e28516. doi: http://dx.doi.org/10.1097/MD.0000000000028516

14. O'Conor CJ, Dash RC, Jones CK, Jiang XS. Performance of repeat cytology with reflex ThyroSeq genomic classifier for indeterminant thyroid cytology. Cancer Cytopathol 2022 Jan 19. doi: http://dx.doi.org/10.1002/cncy.22552

15. Stephenson A, Lau L, Eszlinger M, Paschke R. The thyrotropin receptor mutation database update. Thyroid 2020;30(6):931-5. doi: http://dx.doi.org/10.1089/thy.2019.0807

16. Comer SP, Cullivan S, Szklanna PB, Weiss L, Cullen S, Kelliher S, et al. COVID-19 induces a hyperactive phenotype in circulating platelets. PLoS Biol 2021;19(2):e3001109. doi: http://dx.doi.org/10.1371/journal.pbio.3001109

17. Sahoo SS, Kozyra EJ, Wlodarski MW. Germline predisposition in myeloid neoplasms: Unique genetic and clinical features of GATA2 deficiency and SAMD9/SAMD9L syndromes. Best Pract Res Clin Haematol 2020;33(3):101197. doi: http://dx.doi.org/10.1016/j.beha.2020.101197

18. Rentas S, Pillai V, Wertheim GB, Akgumus GT, Nichols KE, Deardorff MA, et al. Evolution of histomorphologic, cytogenetic, and genetic abnormalities in an untreated patient with MIRAGE syndrome. Cancer Genet 2020;245:42-8. doi: http://dx.doi.org/10.1016/j.cancergen.2020.06.002

19. Sahoo SS, Pastor VB, Goodings C, Voss RK, Kozyra EJ, Szvetnik A, et al. Clinical evolution, genetic landscape and trajectories of clonal hematopoiesis in SAMD9/SAMD9L syndromes. Nat Med 2021;27(10):1806-17. doi: http://dx.doi.org/10.1038/s41591-021-01511-6

20. Xie TA, He ZJ, Liang C, Dong HN, Zhou J, Fan SJ, et al. An integrative bioinformatics analysis for identifying hub genes associated with infection of lung samples in patients infected with SARS-CoV2. Eur J Med Res 2021;26(1):146. doi:http://dx.doi.org/10.1186/s40001-021-00609-4 
21. Thomas ME 3rd, Abdelhamed S, Hiltenbrand R, Schwartz JR, Sakurada SM, Walsh M, et al. Pediatric MDS and bone marrow failure-associated germline mutations in SAMD9 and SAMD9L impair multiple pathways in primary hematopoietic cells. Leukemia 2021;35(11):3232-44. doi: http://dx.doi.org/10.1038/s41375-021-01212-6

22. Otto F, Thornell AP, Crompton T, Denzel A, Gilmour KC, Rosewell IR, et al. Cbfa1, a candidate gene for cleidocranial dysplasia syndrome, is essential for osteoblast differentiation and bone development. Cell 1997;89(5):765-71. doi: http://dx.doi.org/10.1016/s0092-8674(00)80259-7

23. Matthijssens F, Sharma ND, Nysus M, Nickl CK, Kang H, Perez DR, et al. RUNX2 regulates leukemic cell metabolism and chemotaxis in high-risk T cell acute lymphoblastic leukemia. J Clin Invest 2021;131(6):e141566. doi: http://dx.doi.org/10.1172/JCl141566

24. Ott CE, Leschik G, Trotier F, Brueton L, Brunner HG, Brussel W, et al. Deletions of the RUNX2 gene are present in about $10 \%$ of individuals with cleidocranial dysplasia. Hum Mutat 2010;31(8):E1587-93. doi: http://dx.doi.org/10.1002/humu.21298

25. Scheps KG, Francipane L, Nevado J, Basack N, Attie M, Bergonzi MF, et al. Multiple copy number variants in a pediatric patient with $\mathrm{Hb} \mathrm{H}$ disease and intellectual disability. Am J Med Genet $\mathrm{A}$ 2016;170A(4):986-91. doi: http://dx.doi.org/10.1002/ajmg.a.37532

26. Varvagiannis K, Stefanidou A, Gyftodimou Y, Lord H, Williams L, Sarri C, et al. Pure de novo partial trisomy $6 p$ in a girl with craniosynostosis, Am J Med Genet A 2013;161:343-51. doi: http://dx.doi.org/10.1002/ajmg.a.35727

27. Greives MR, Odessey EA, Waggoner DJ, Shenaq DS, Aradhya S, Mitchell A, et al. RUNX2 quadruplication: additional evidence toward a new form of syndromic craniosynostosis. J Craniofac Surg 2013;24:126-9. doi: http://dx.doi.org/10.1097/SCS.0b013e31826686d3

28. Cuellar A, Bala K, Di Pietro L, Barba M, Yagnik G, Liu JL, et al. Gain-of-function variants and overexpression of RUNX2 in patients with nonsyndromic midline craniosynostosis. Bone 2020;137:115395. doi: http://dx.doi.oeg/10.1016/j.bone.2020.115395

29. Olsson B, Calixto RD, da Silva Machado NC, Meger MN, Paula-Silva FWG, Rebellato NLB, et al. MSX1 is differentially expressed in the deepest impacted maxillary third molars. $\mathrm{Br} \mathrm{J}$ Oral Maxillofac Surg 2020;58(7):789-794. doi: http://dx.doi.org/10.1016/j.bjoms.2020.04.006

30. Koch FP, Merkel C, Al-Nawas B, Smeets R, Ziebart T, Walter C, et al. Zoledronate, ibandronate and clodronate enhance osteoblast differentiation in a dose dependent manner-a quantitative in vitro gene expression analysis of DIx5, Runx2, OCN, MSX1 and MSX2. J Craniomaxillofac Surg 2011;39(8):562-9. doi: http://dx.doi.org/10.1016/j.jcms.2010.10.007

31. Jin $A$, Hong $Y$, Yang $Y, X u H$, Huang $X$, Gao $X$, et al. FOXO3 mediates tooth movement by regulating force-induced osteogenesis. J Dent Res 2022;101(2):196-205. doi: http://dx.doi.org/10.1177/00220345211021534

32. Kraemer S, Rothe K, Pfaeffle R, Fuehrer-Sakel D, Till H, Muensterer OJ. Activating TSH-receptor mutation (Met453Thr) as a cause of adenomatous non-autoimmune hyperthyroidism in a 3-year-old 
boy. J Pediatr Endocrinol Metab 2009;22(3):269-74. doi:

http://dx.doi.org/10.1515/jpem.2009.22.3.269

33. Abe E, Marians RC, Yu W, Wu XB, Ando T, Li Y, et al. TSH is a negative regulator of skeletal remodeling. Cell 2003;115(2):151-62. doi: http://dx.doi.org/10.1016/s0092-8674(03)00771-2

34. Gao H, Lu X, Huang H, Ji H, Zhang L, Su Z. Thyroid-stimulating hormone level is negatively associated with fertilization rate in patients with polycystic ovary syndrome undergoing in vitro fertilization. Int J Gynaecol Obstet 2021;155(1):138-45. doi: http://dx.doi.org/10.1002/ijgo.13581

35. Botzenhart EM, Bartalini G, Blair E, Brady AF, Elmslie F, Chong KL, et al. Townes-Brocks syndrome: twenty novel SALL1 mutations in sporadic and familial cases and refinement of the SALL1 hot spot region. Hum Mutat 2007;28(2):204-5. doi: http://dx.doi.org/10.1002/humu.9476

36. Chakravarthi VP, Ratri A, Masumi S, Borosha S, Ghosh S, Christenson LK, et al. Granulosa cell genes that regulate ovarian follicle development beyond the antral stage: The role of estrogen receptor $\beta$. Mol Cell Endocrinol 2021;528:111212. doi: http://dx.doi.org/10.1016/j.mce.2021.111212

37. Basta JM, Singh AP, Robbins L, Stout L, Pherson M, Rauchman M. The core SWI/SNF catalytic subunit Brg1 regulates nephron progenitor cell proliferation and differentiation. Dev Biol 2020;464(2):176-87. doi: http://dx.doi.org/10.1016/j.ydbio.2020.05.008

38. Sfakianoudis K, Simopoulou M, Grigoriadis S, Pantou A, Tsioulou P, Maziotis E, et al. Reactivating ovarian function through autologous platelet-rich plasma intraovarian infusion: Pilot data on premature ovarian insufficiency, perimenopausal, menopausal, and poor responder women. J Clin Med 2020;9(6):1809. doi: http://dx.doi.org/10.3390/jcm9061809

39. Herget-Rosenthal S, Bökenkamp A, Hofmann W. How to estimate GFR-serum creatinine, serum cystatin C or equations? Clin Biochem 2007;40(3-4):153-61. doi: http://dx.doi.org/10.1016/j.clinbiochem.2006.10.014

40. Chen S, Li J, Liu Z, Chen D, Zhou L, Hu D, et al. Comparing the value of cystatin-C and serum creatinine for evaluating the renal function and predicting prognosis of COVID-19 patients. Front Pharmacol 2021;12:587816. doi: http://dx.doi.org/10.3389/fphar.2021.587816

41. Keel S, Geddis A. The clinical and laboratory evaluation of patients with suspected hypocellular marrow failure. Hematology Am Soc Hematol Educ Program 2021;2021(1):134-42. doi: http://dx.doi.org/10.1182/hematology.2021000244

\section{Table 1}

Table 1. Summary of complete blood count, differential and immunoglobulin data measured in healthy $46, \mathrm{XX}$ with new variants in RUNX2, SALL1, and SAMD9. 


\begin{tabular}{|c|c|c|}
\hline ABS CD19+(uL) & 153 & $12-645$ \\
\hline$\% \mathrm{CD} 19^{+}(\%)$ & 6.1 & 3.3-25.4 \\
\hline $\mathrm{ABS} \mathrm{CD}^{+}(\mathrm{uL})$ & 2325 & $622-2402$ \\
\hline$\% \mathrm{CD}^{+}(\%)$ & 93 & $57.5-86.2$ \\
\hline ABS $\mathrm{CD} 4^{+}$helper & 868 & $359-1519$ \\
\hline$\% \mathrm{CD}^{+}(\%)$ & 34.7 & $30.8-58.5$ \\
\hline $\mathrm{ABS} \mathrm{CD}^{+}(\mathrm{uL})$ & 1055 & $109-897$ \\
\hline$\% \mathrm{CD}^{+}(\%)$ & 42.2 & $12-35.5$ \\
\hline CD4/CD8 & 0.82 & $0.92-3.72$ \\
\hline ABS NK (CD56/16) & 8 & $24-406$ \\
\hline$\%$ NK (\%) & 0.3 & $1.4-19.4$ \\
\hline WBC $\left(x 10^{3} / \mathrm{uL}\right)$ & 5.5 & $3.4-10.8$ \\
\hline $\mathrm{RBC}\left(\mathrm{x} 10^{6} / \mathrm{uL}\right)$ & 3.36 & $3.77-5.28$ \\
\hline $\mathrm{HGB}(\mathrm{g} / \mathrm{dL})$ & 12.1 & $11.1-15.9$ \\
\hline HCT (\%) & 35.6 & $34.0-46.6$ \\
\hline $\mathrm{MCV}(\mathrm{fL})$ & 106 & $79-97$ \\
\hline $\mathrm{MCH}(\mathrm{pg})$ & 36 & $26.6-33$ \\
\hline $\mathrm{MCHC}(\mathrm{g} / \mathrm{dL})$ & 34 & $31.5-35.7$ \\
\hline RDW (\%) & 11.3 & $11.7-15.4$ \\
\hline PLT (x103/uL) & 229 & $150-450$ \\
\hline
\end{tabular}

\begin{tabular}{|lcc|}
\hline neutrophils (\%) & 47 & - \\
\hline lymphocytes (\%) & 45 & - \\
\hline monocytes (\%) & 8 & - \\
\hline
\end{tabular}




\begin{tabular}{lll} 
eosinophils (\%) & 0 & - \\
\hline basophils $(\%)$ & 0 & -
\end{tabular}

\begin{tabular}{lll}
\hline ABS neutrophils $\left(\times 10^{3} / \mathrm{uL}\right)$ & 2.6 & $1.4-7$ \\
\hline ABS lymphocytes $\left(\times 10^{3} / \mathrm{uL}\right)$ & 2.5 & $0.7-$ \\
\hline ABS monocytes $\left(\times 10^{3} / \mathrm{uL}\right)$ & 0.4 & $0.1-0.9$ \\
\hline ABS eosinophils $\left(\times 10^{3} / \mathrm{uL}\right)$ & 0 & $0-0.4$ \\
\hline ABS basophils $\left(\times 10^{3} / \mathrm{uL}\right)$ & 0 & $0-0.2$ \\
\hline
\end{tabular}

\begin{tabular}{lll}
\hline Immature gran $(\%)$ & 0 & - \\
\hline ABS Immature gran $\left(\times 10^{3} / \mathrm{uL}\right)$ & 0 & - \\
\hline
\end{tabular}

\begin{tabular}{lll}
\hline $\lg$ - total $(\mathrm{g} / \mathrm{dL})$ & 2.4 & $1.5-4.5$ \\
\hline $\lg A(\mathrm{mg} / \mathrm{dL})$ & 64 & $87-352$ \\
\hline $\lg (\mathrm{mg} / \mathrm{dL})$ & 559 & $719-1475$ \\
\hline $\lg M(\mathrm{mg} / \mathrm{dL})$ & 197 & $58-230$ \\
\hline
\end{tabular}

Notes: $\mathrm{ABS}=$ absolute, $\mathrm{NK}=$ natural killer cell, $\mathrm{lg}=$ immunoglobulin, red $=$ above normal, blue $=$ below normal; $(-)$ indicates reference range not specified/undefined.

\section{Figures}



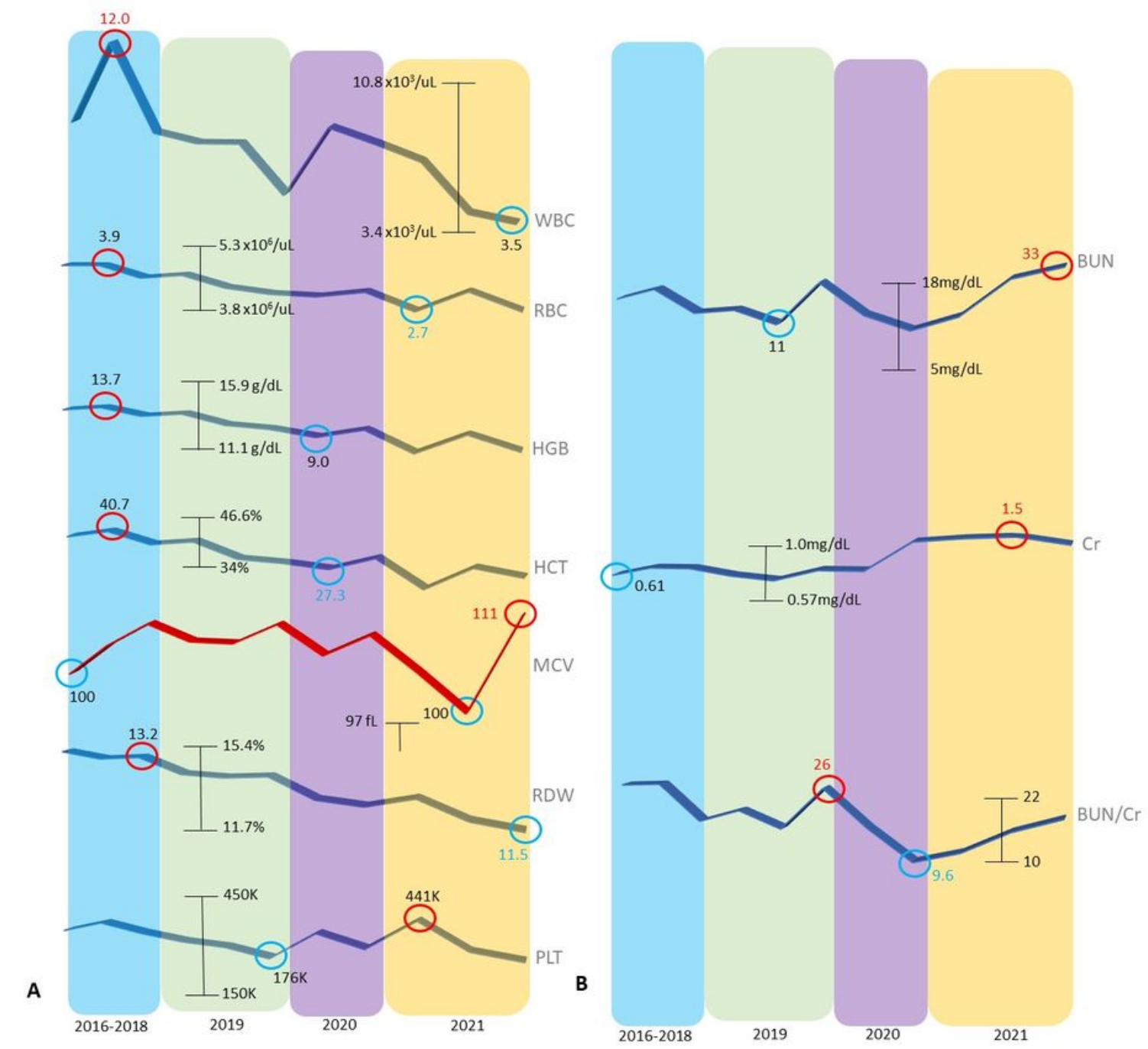

\section{Figure 1}

Trends and high/low screening results for (A) hematopoiesis via complete blood count and

(B) renal function via BUN/Creatinine, 2016-2021. Note persistently elevated MCV (red line). Maximum and minimum values for parameters are circled (abnormal high=red; abnormal low=blue). 


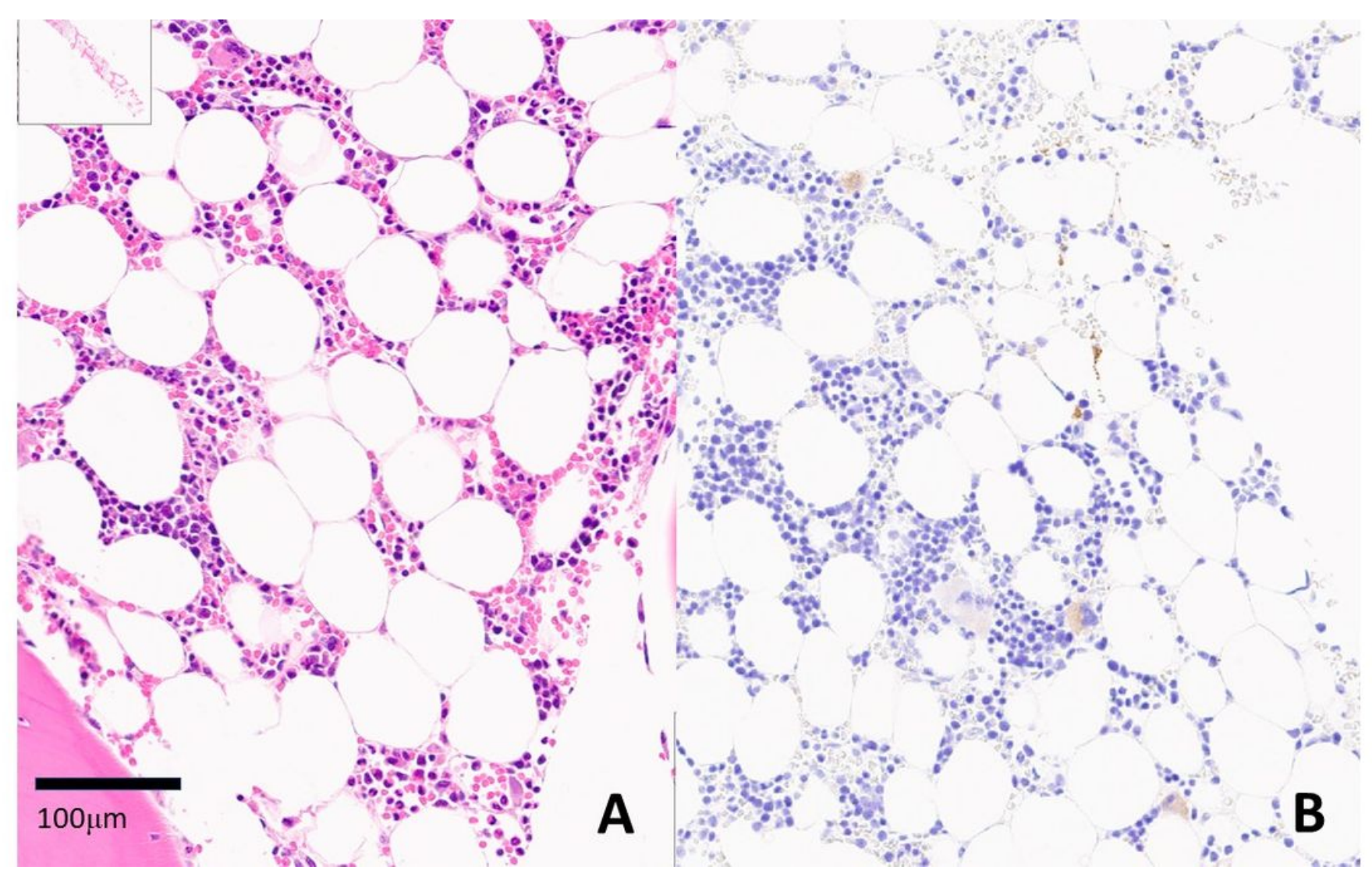

Figure 2

Marrow hypocellularity with compound heterozygous variants involving RUNX2, SALL1, and SAMD9, showing predominant adipose cells and reduced hematopoiesis; A) H\&E stain, B) CD61 stain (x20). 


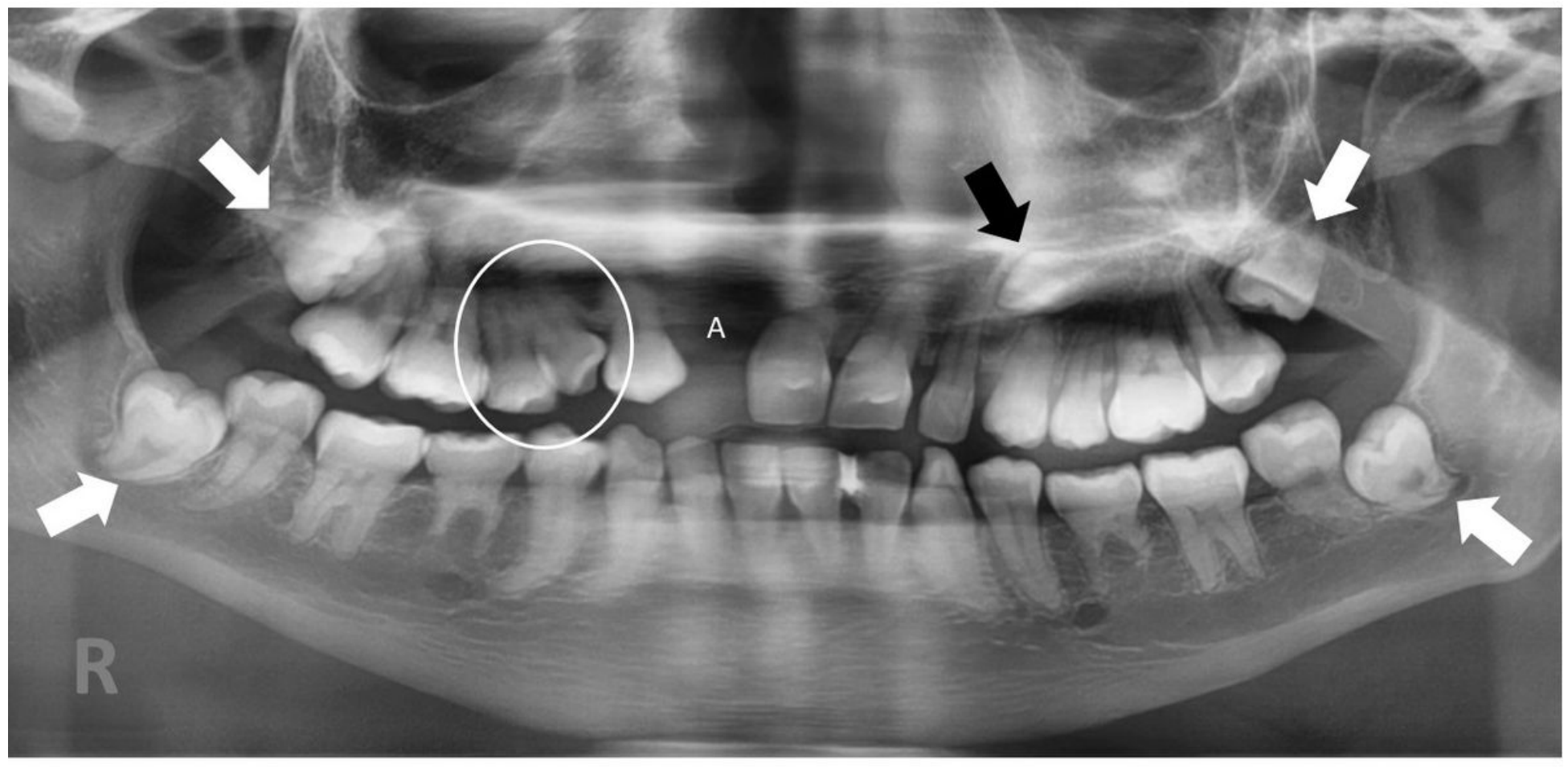

\section{Figure 3}

Panorex view at age 17yrs indicating third molar impaction (white arrows), near-horizontal malposition of left maxillary cuspid (black arrow), and contralateral cuspid/bicuspid transposition (circle). Diffuse root hypoplasia likely contributed to loss of right maxillary lateral incisor (A). 